Danijela Despotović ${ }^{1}$ Slobodan Cvetanović ${ }^{2}$ Vladimir Nedić ${ }^{3}$
JEL: 030

DOI: 10.5937/industrija1-9365

UDC: 005.591 .6

005.332:330.341.1

Original Scientific Paper

\title{
Analysis of innovativeness, as a determinant of competitiveness of the selected European countries
}

\author{
Article history: \\ Received: 28 October 2015 \\ Sent for revision: 19 November 2015 \\ Received in revised form: 5 February 2016 \\ Accepted: 20 February 2016 \\ Available online: 1 April 2016
}

\begin{abstract}
Starting from the premise that the phenomenon of innovation is at the heart of modern economic policies, the focus of the paper is on the most innovative and least innovative European countries, based on the values of the 12th pillar of the Global Competitiveness Index (GCI) - Innovation. The research centres on the analysis of the selected countries, observing them as 10 innovation leaders and 10 innovation learners of Europe in 2013. Cluster analysis of the selected countries shows the depth of the gap between the formed clusters of innovation leaders and innovation learners. By applying the method of visualisation, the paper examines the components of the pillar Innovation in respect of these countries. With regard to the clusters formed and a big difference between them, the further course of the research includes the time dimension and analyses the trend of innovativeness in the studied groups of countries for the period 2006 - 2015. The time series graphs for each of the clusters, according to indicators of Innovation, with average values per cluster have been constructed, showing also the trend lines for each of the clusters. Bearing in mind that the majority of macroeconomic time series exhibits time dependence, dynamic relations between them are analysed using the VAR model. Statistically significant interdependence is established between the observed series. Furthermore, through simple linear regression, the impact of innovativeness on GDP per capita of the observed group of countries is examined. It can be concluded that, in addition to the pronounced gap between the achieved levels of innovativeness of the
\end{abstract}

\footnotetext{
${ }^{1}$ University of Kragujevac, Faculty of Economics, Serbia, ddespotovic@ kg.ac.rs

2 University of Niš, Faculty of Economics, Serbia

${ }^{3}$ University of Kragujevac, Faculty of Philology and arts, Serbia
} 
Despotović $D$. et al.: Analysis of innovativeness, as a determinant of competitiveness...

observed groups of countries, there is a positive impact of innovativeness on the achieved level of GDP per capita, expressed in the purchasing power of the domestic currency on the part of the group of innovation "learners" in the reporting time period.

Keywords: innovation, innovativeness, divergence, innovation learners, innovation leaders, Europe

\section{Analiza inovativnosti kao determinante konkurentnosti selektovanih zemalja Evrope}

Apstrakt: Polazeći od pretpostavke da je fenomen inovativnosti u srži savremene ekonomske politike, $u$ radu se posmatraju najinovativnije $i$ najmanje inovativne evropske zemlje, a na osnovu vrednosti 12 . stuba Indeksa globalne konkurentnosti (IGK) - Inovacije. Istraživanje je bazirano na analizi selektovanih 10 inovacionih lidera i 10 inovacionih "početnika" zemalja Evrope u 2013. Putem klaster analize izabranih zemalja na osnovu sličnosti inovativnih performansi, prikazana je dubina jaza između formiranih klastera inovacionih lidera $i$ inovacionih "početnika". Primenom metode vizuelizacije sagledavane su komponente stuba Inovacije analiziranih grupa zemalja. $U$ dalji tok istraživanja, uključena je vemenska dimenzija $i$ analiziran je trend inovativnosti posmatranih grupa zemalja u periodu od 2006 - 2015. godine. Grafikoni vremenskih serija, sa prosečnim vrednostima inovativnosti, pokazuju trend linije za svaki od klastera. Imajući u vidu da najveći broj makroekonomskih vremenskih serija ispoljava vremensku zavisnost, dinamički odnosi između njih analizirani su primenom VAR modela. Izmedju posmatranih serija ustanovljena je statisticki znacajna medjuzavisnost. Dodatno je, putem proste linearne regresije, ispitivan uticaj inovativnosti na GDP per capita posmatranih grupa zemalja. Došlo se do zaključka da pored izraženog jaza izmedju dostignutih nivoa inovativnosti posmatranih grupa zemalja postoji $i$ pozitivan uticaj inovativnosti na dostignuti nivo GDP per capita izraženog u kupovnoj moći domaće valute kod grupe inovacionih "početnika" u posmatranom vremenskom periodu.

Ključne reči: inovacija, inovativnost, divergencija, inovacioni "početnici", inovacioni lideri, Evropa

\section{Introduction}

Innovation brings new products, processes, services, and functionality into the production, the market, and the society, which consumers and organisations find useful and valuable. 
Despotović $D$. et al.: Analysis of innovativeness, as a determinant of competitiveness...

It is most commonly observed at the level of products or processes, whereby innovative product meets the needs of consumers, while process innovation improves organisational efficiency and effectiveness (Smith, 2010). Innovativeness is associated with creativity and converting new ideas into tangible goods and services through inventions, research, and development of new products. It turned out, however, that the improvement of innovativeness of some countries, in addition to research and development activities, depends on a number of other factors (Dodgston, Gann \& Salter, 2008; Cvetanovic et al., 2014; Nedic, Cvetanović \& Despotovic, 2014). A number of innovations are the result of improved methods of work organisation in companies and their interaction with related companies and the academic community (Freeman, 1987; 1995; 2002; 2008).

Innovation is a key driver of company success (Rothwell, 1994; Zahra et al., 1999; Bolwijn, \& Kump, 1990; Jobber, 2001). In modern business conditions, creativity is becoming a key dimension of innovative thinking, so that only those companies that are able to explicitly manage their own creativity through innovation can take a leadership position on the increasingly demanding world market (Amidon, 2003; Zubović, 2012).

Innovation is the key to economic growth, increase in employment, meaning that it is the most important determinant of sustainable growth of living standard (Cimoli \& Dosi, 1995; Despotovic, Cvetanović \& Nedić, 2014). When creating innovation in some country, innovators support processes, develop and exchange information, knowledge, experience, and other resources (Lundvall (ed), 1992; Edquist (ed) 1997).

Under such circumstances, networks are becoming increasingly important in the process of creating innovation, which is logical given that the knowledge that is much faster generated through innovation stands for a prerequisite of a better position of the company in relation to the competition (Fagerberg, Mowery \& Nelson, 2004). Moreover, complexes of innovation and innovativeness are increasingly pronounced at the epicenter of the technological and economic sovereignty of countries globally, starting with the industrial revolution in the 18th century until the present day (Atkinson \& Ezel, 2012).

Considering the most efficient ways out of the latest economic crisis that the USA and Europe could take, Foray and Phelps point out that the promotion of innovation is the only appropriate method for their return to the path of longterm sustainable growth (Foray \& Phelps, 2010). Porter and Rivkin generally accept this view by noting that the strategy of improving innovativeness in the United States assumes the consensus of private and public sector in terms of the responsibility for the research and technological development and incomparably stronger involvement of small and medium entrepreneurs in the process (Porter \& Rivkin, 2012). Thus, the new US strategy linked to 
Despotović $D$. et al.: Analysis of innovativeness, as a determinant of competitiveness...

innovation aims to regain leadership of US in the basic research, by investing in human capital and stimulating entrepreneurship based on innovation. According to the 2009 Panel on Future EU Innovation Policy, government policy plays a major role in raising innovativeness of the economy. Innovation policy should be designed to support individual economic actors to develop new skills, knowledge, and demand channels (OECD, 2009).

\section{Subject and research hypotheses}

The subject of research in the paper deals is the complex of innovativeness (12th pillar of the $\mathrm{GCl}$ ) of European countries in the period 2006-2015. The main problem to be studied can be reduced to the question: are there major differences in innovativeness and is it realistic to expect convergence of European countries in respect of innovativeness in the near future? In the context of this issue, the subject of research involves the identification of the depth of the gap between the two groups of European countries: innovation leaders and innovation learners. Recognition of an area where such significant differences in the expressed level of innovativeness come from is particularly important for overcoming the existing gap. The following hypotheses have been set in line with the defined research objective:

H1. There is a pronounced gap in respect of innovativeness among the European countries, and it is, among other things, the result of different approaches to innovation policy, as an increasingly important component of economic policy.

$\mathrm{H} 2$ There is significant time interdependence between the achieved levels of innovativeness of EU innovation leaders and EU innovation learners.

H3. Improving innovativeness, with respect to the clause ceteris paribus, can have a significant impact on the achieved level of GDP per capita (PPP) of innovation learners.

\section{Research methodology}

A special aspect of the imperative of improving innovativeness that companies and countries are facing relates to the quantification of this process. Measuring innovativeness is significant because the results are the basis for defining development policies and are an essential element of their implementation. In order for a development policy to be successful and effective, its effects must be monitored and evaluated, in order to, if needed, make the necessary adjustments and changes in individual segments. 
Despotović $D$. et al.: Analysis of innovativeness, as a determinant of competitiveness...

The traditional approach to measuring innovativeness of countries is based on parameters such as the number of patents and published papers in scientific journals per million inhabitants, that is, investment in research and development, and so on (Greenhalgh \& Rogers, 2010). However, in parallel with the affirmation of the view that innovation is a multidimensional phenomenon, for evaluating the achieved innovativeness of some countries, the so-called composite indices are more frequently used. Their use in a number of different annual reports points to the ranking of countries on the basis of various innovative features. Since there are plenty of definitions of innovativeness of organisations and countries, it is logical that there are a number of different approaches to its measurement. This is related to the possibility of finding studies that deal with similar subjects, which are mutually different in respect of the results obtained. Furthermore, analyses of innovativeness primarily focus on the innovative leaders or countries characterised by the biggest change of intensity of improvement of innovativeness, while countries with modest innovative performance are given far less attention.

Many countries performed the analysis and evaluation of their own innovative performance for their needs. The compromise in respect of the comparability of data, relating to the necessity of respecting the specifics of individual national innovation systems and innovation policies, must often be made. Studies of this type usually include three different levels: analysis and evaluation of national innovation programmes, analysis and evaluation of innovative institutions, and analysis and evaluation of institutional programmes, institutions, and development of a competitive environment (EU Innovation, 2005) Numerous studies focus on econometric determinants of innovation activities (Boia, Conceição \& Santos, 2003), as well as consideration of the overall effects of subsidizing innovation activity (Hujer \& Radic, 2005; Takalo, Tanayama \& Toivanen, 2008).

This paper relies on the value of the 12th pillar of the Global Competitiveness Index (GCl) of the World Economic Forum, Innovation, as an indicator of innovativeness (Fig.1). Therefore, innovativeness presented in this manner is one of the twelve components of the global competitiveness index, but is itself made up of the following elements: Capacity for innovation, Quality of scientific research institutions, company spending on $E$ \& $D$, Universityindustry collaboration in $\mathrm{R} \& \mathrm{D}$, Government procurement of advanced tech products and engineers, Availability of scientists and engineers and PCT patents applications/million population (The Global Competitiveness Report 2013-2014, p. 51). 
Despotović $D$. et al.: Analysis of innovativeness, as a determinant of competitiveness...

Figure 1: Composition of 12. GCI pillars

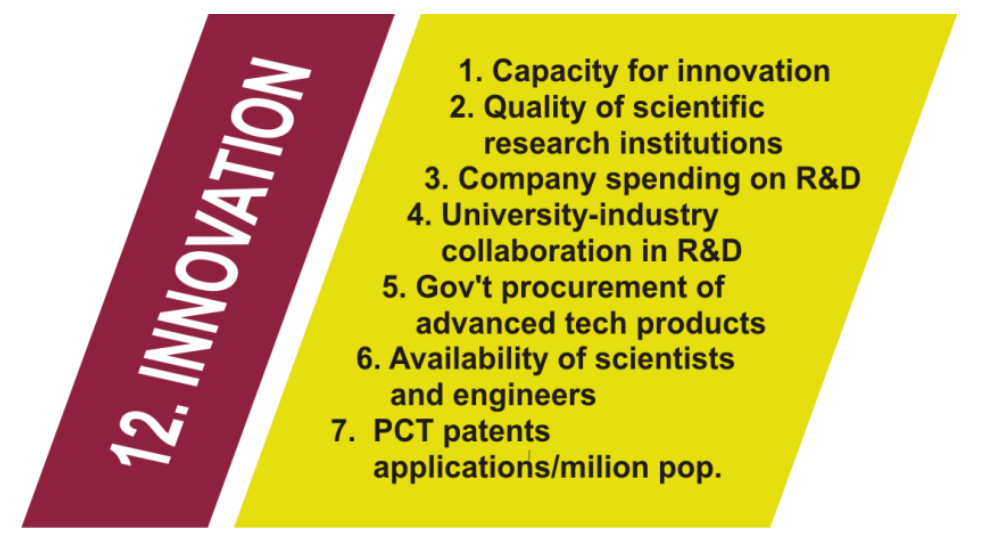

Source: Modified according to: The Global Competitiveness Report 2013-2014, p. 9

In order to get acceptable answers to the research question, or test the established hypotheses, the paper relies on the following analytical methods:

- Cluster analysis, based on the parameters of innovativeness, in order to explain the depth of the gap between the European countries - innovation leaders and innovation learners.

- Time graph of innovativeness of ten leading and ten lagging European countries in respect of innovativeness in the period 2006-2015, in order to identify trend of innovativeness of the observed groups of countries.

- VAR model, given that the majority of macroeconomic time series exhibits time dependence, which requires the formulation of a model to allow for the analysis of dynamic relationships between variables.

- Diagrams of correlation between innovativeness and GDP per capita in ten leading and ten lagging European countries in respect of innovativeness in the period 2006-2013.

\section{Results and discussion}

Based on the 2013 data on the values of the 12th pillar of the $\mathrm{GCl}$, Innovation, 15 most innovative European countries (innovation leaders) and 15 least innovative European countries (innovation learners) in 2013 were initially selected. 


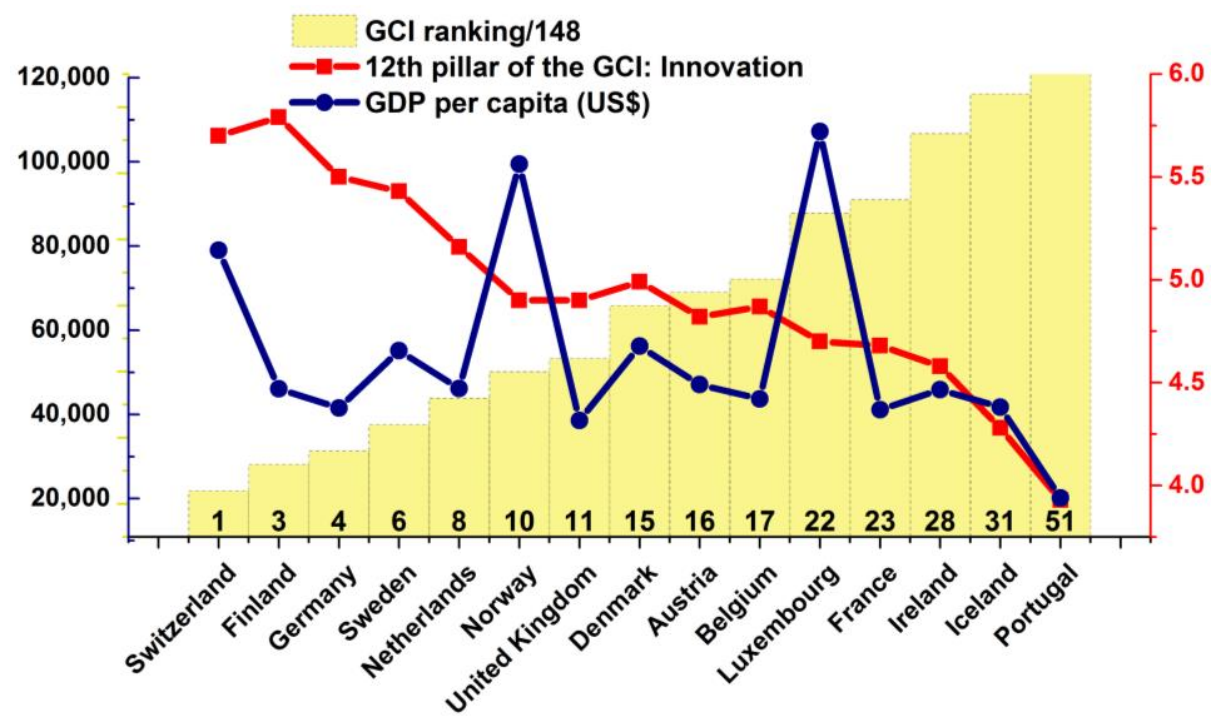

Source: Authors, with reference to: The Global Competitiveness Report 2013-2014, World Economic Forum.

The data contained in Fig. 2 clearly show that the most innovative economies are at the same time the most economically developed countries. Finland, Switzerland, Germany, Sweden, and the Netherlands are leaders in innovativeness among the European countries. Fifteen European innovation leaders are not big countries, in terms of the territory and the population. Moreover, most of them are relatively small countries (with the exception of Germany, France, and the UK). Each of these countries has less than 0.5 percent of the world population. It can be said that in addition to the old European innovation leaders (Central Europe: Switzerland, Germany, the Netherlands, and Northern Europe: Sweden, Denmark, Finland), in recent times, Ireland, Iceland, and Portugal have found themselves in the group of European top 15 innovative economies. Moreover, Finland, Sweden, Denmark, and Ireland have in many areas reached or even overcome the level of innovative capability of major European countries, especially Britain, France, and Italy, whose economic situation was much more favourable in the early 1980s than it is today (Atkinson \& Ezell, 2012).

In the group of European innovation learners in 2013, alongside Ukraine, Greece, Russian Federation, Cyprus, and Turkey, there are former socialist 
Despotović $D$. et al.: Analysis of innovativeness, as a determinant of competitiveness...

countries of which one number today belongs to the EU28 (Poland, Latvia, Slovakia, Bulgaria, Romania, and Croatia), as well as five Western Balkan countries (Albania, Serbia, Macedonia, Bosnia and Herzegovina, Montenegro). All of them, with the exception of Poland and Turkey to some extent, are also extremely behind other European countries based on the level of competitiveness (Fig. 3).

Figure 3. 12th pillar of the GCl, GDP pc, and GCl ranking of European learners in 2013

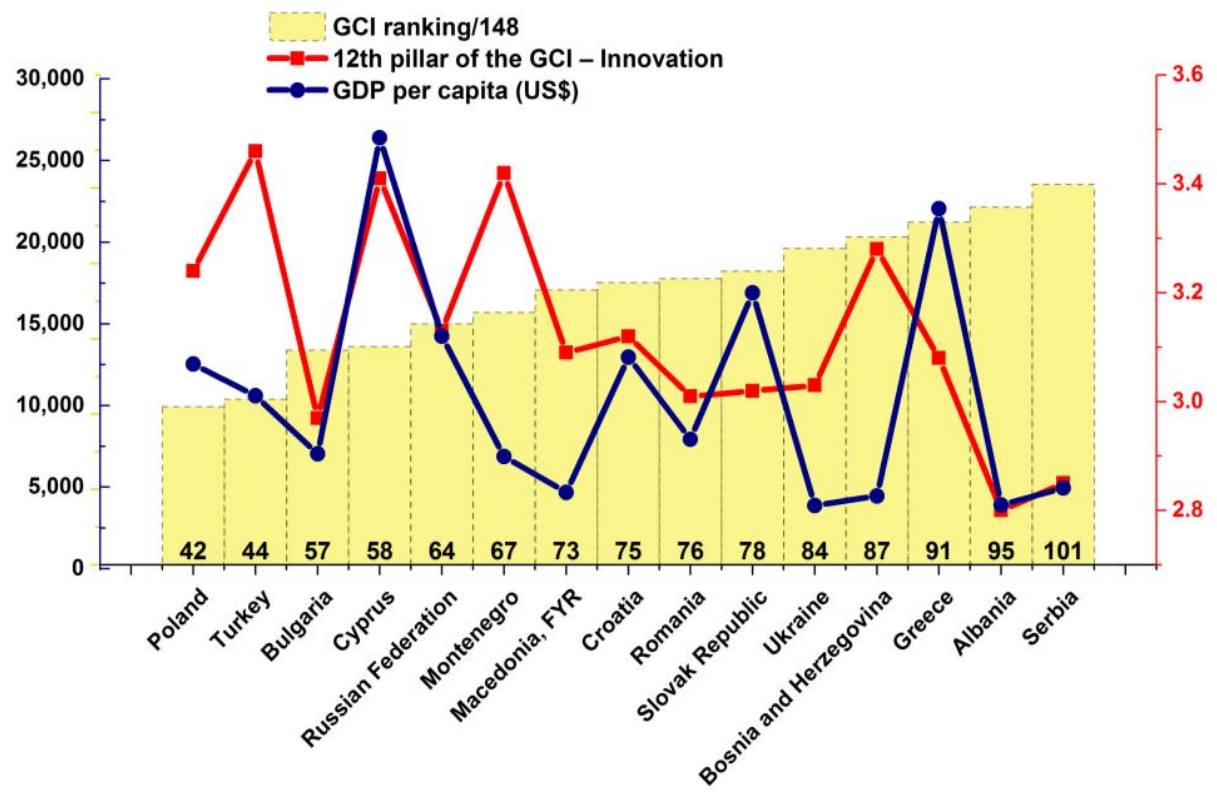

Source: Authors, with reference to: The Global Competitiveness Report 2013-2014, World Economic Forum.

In the second step, the selected countries were classified into 10 leading and 10 lagging countries (Fig. 4). After the decision to perform 10+10 analysis, the last five countries (Luxembourg, France, Ireland, Iceland, and Portugal) were excluded from the top 15 list.

Ten most innovative European countries were in the third stage of development (innovation-driven stage). From the list of 15 lagging European countries in terms of innovativeness, Russian Federation, Ukraine, and Turkey, as major economies, and Montenegro and Cyprus, as micro states, were not taken into account (Schwab, 2011; Dutta, 2012). Six countries from 
Despotović $D$. et al.: Analysis of innovativeness, as a determinant of competitiveness...

the list of least innovative European economies (Albania, Bosnia and Herzegovina, Bulgaria, Poland, Romania, and Serbia) in 2013 were found in the efficiency-driven stage, Croatia, Slovakia, and Poland were in transition from stage 2 to stage 3, while Greece was in the innovation-driven stage of development (The Global Competitiveness Report 2013-2014).

Figure 4. Map of countries

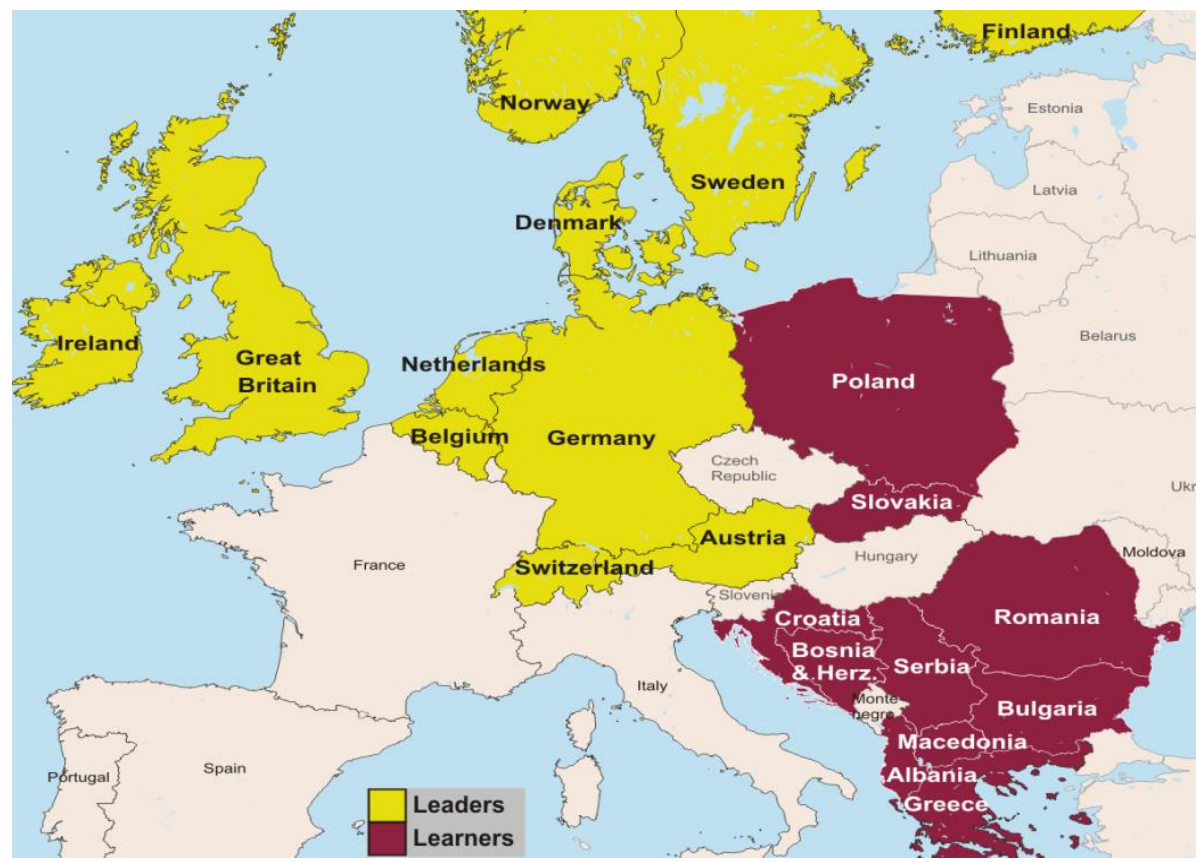

\subsection{Cluster analysis based on the parameters of innovativeness}

For the purpose of classification of the selected countries into two or more groups, based on similarities in innovative performance, cluster analysis of the selected countries was carried out. The intention was to use these multivariate techniques to show the depth of the gap between the formed clusters of European innovation leaders and innovation learners. 
Despotović $D$. et al.: Analysis of innovativeness, as a determinant of competitiveness...

Figure 5. Dendrogram of cluster analysis based on the parameters of innovativeness
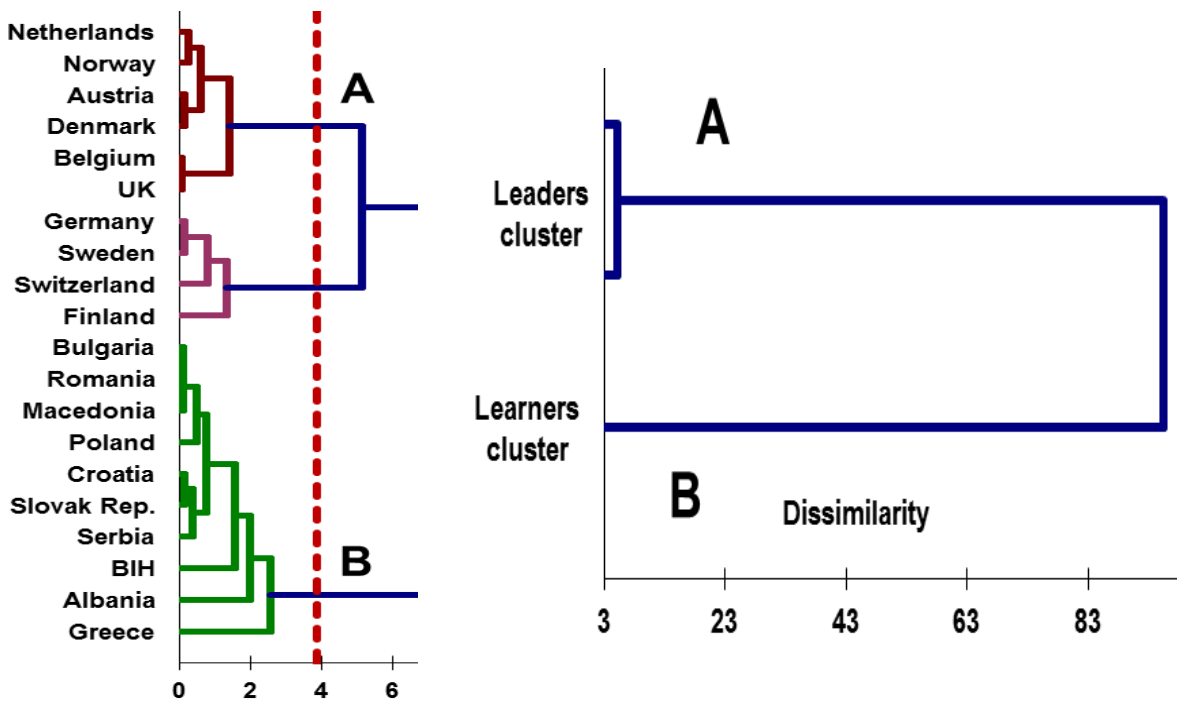

Source: Authors, with reference to: The Global Competitiveness Report 2013-2014, World Economic Forum.

In the process of grouping the 20 selected countries (Fig. 5 on the left), we used a bottom-up method of agglomerative hierarchical clustering. In the initial step, each country was treated as a separate cluster. Their grouping into pairs of clusters, based on similarities in terms of the values of the observed variables, is the result of all subsequent iterations until the observed entities became consolidated within a single cluster. If the level of difference less than 5 is taken as a possible cross-section of the dendrogram, three clusters of observed countries are clearly identified. The first two clusters include 10 innovation learners, i.e. $50 \%$ of the surveyed countries. Specifically, the first cluster consists of four countries from the group of innovation leaders (Germany, Sweden, Finland, and Switzerland), while the second cluster involves the remaining six countries, innovative leaders (UK, Belgium, the Netherlands, Denmark, Austria, and Norway). The third cluster is composed of all ten countries from the group of innovative learners. At the level of difference of more than 5, two clusters of innovation leaders are merged into one, so that, finally, the two clusters of the observed countries are formed: leaders and learners (Fig.5 on the right). Between the formed clusters there is a big discrepancy, because only at the level of difference of more than 90, their grouping within a single cluster can be ensured. This supports the hypothesis $\mathrm{H} 1$. 
Despotović $D$. et al.: Analysis of innovativeness, as a determinant of competitiveness...

Among the countries within the clusters, there are extremely small differences (Fig. 6).

Figure 6. Dendrogram of cluster analysis based on the parameters of innovativeness for innovative learners and innovative leaders
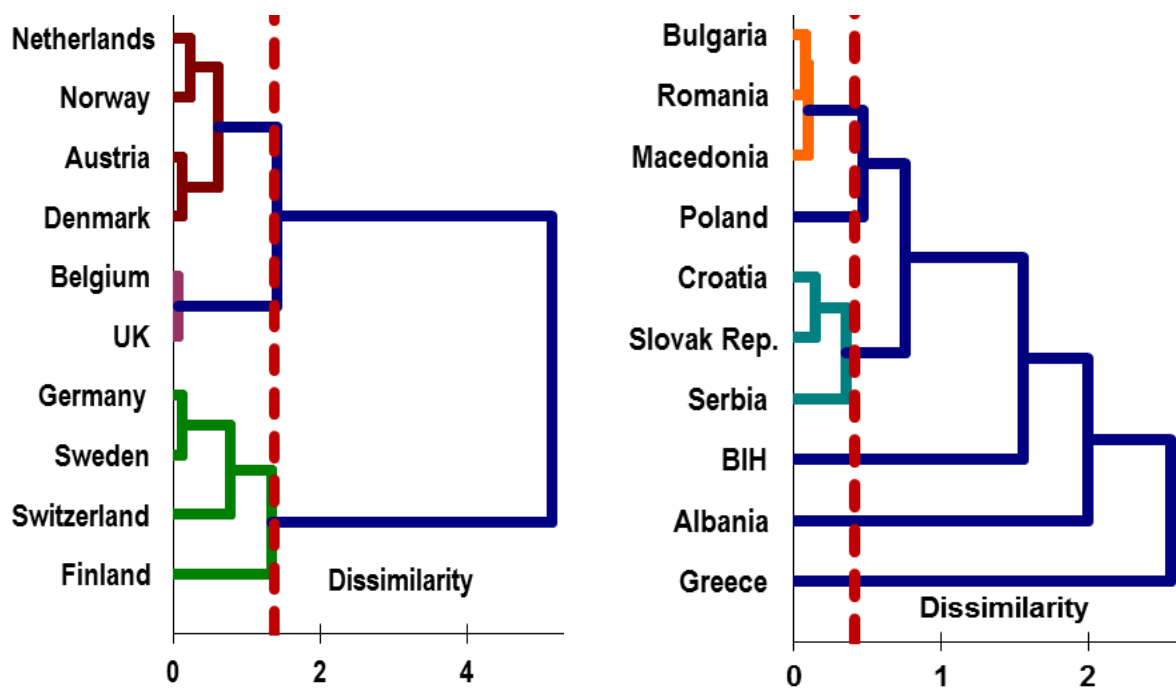

Source: Authors, with reference to: The Global Competitiveness Report 2013-2014, World Economic Forum.

Due to this fact, the next step involves a simple comparison of the characteristics of innovativeness of the selected groups of European countries.

\subsection{Comparative analysis based on the parameters of innovativeness}

In order to see where such significant differences in the expressed level of innovativeness come from, Fig. 7 gives a comparative overview of the innovative performance of groups of countries, innovation leaders, on the one hand, and the innovation learners, on the other hand. Innovative performance of the observed countries is determined on the basis of the components of the twelfth column of the $\mathrm{GCl}$, Innovation: Capacity for innovation, Quality of scientific research institutions, Company spending on E\&D, Universityindustry collaboration in R\&D, Government procurement of advanced tech products and engineers, Availability of scientists and engineers and PCT patents applications/million population. Fig. 7 provides a comparison by elements of the 12th pillar except that the parameter 12.07 PCT - patents 
Despotović $D$. et al.: Analysis of innovativeness, as a determinant of competitiveness...

applications / million population is omitted since it is not comparable with other parameters of the Innovation components.

Figure 7. Comparison by elements of the 12th pillar of the GCl in 2013

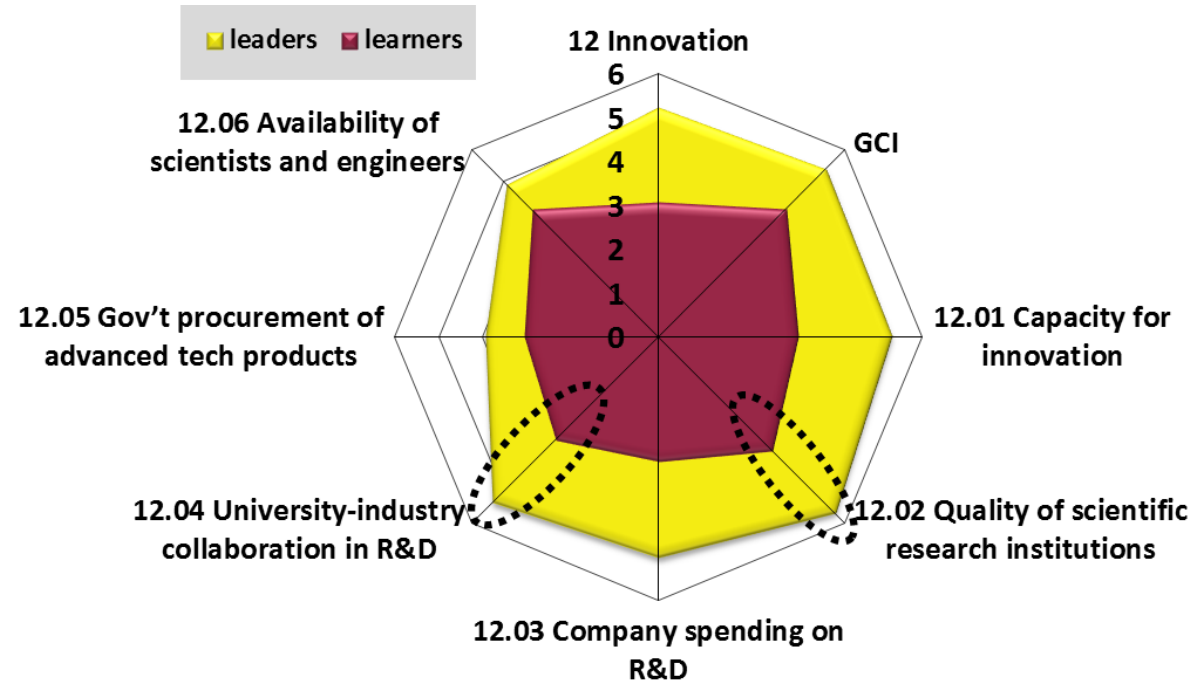

Source: Authors, with reference to: The Global Competitiveness Report 2013-2014, World Economic Forum

It is obvious that the gap in terms of the values of the $12^{\text {th }}$ pillar, Innovation, among the selected groups of countries in 2013, is high. The largest discrepancies are related to University-industry collaboration in R\&D and Quality of scientific research institutions, and the least in relation to Availability of scientists and engineers.

It can be noted that most European innovation leaders have shaped their national innovation strategies. Finland, for example, has a national innovation authority, Tekes, founded in 1983. VINNOVA is Sweden's national innovation authority, which began operation in 2003. Denmark established a National Agency for Science, Technology, and Innovation in 2006. The Netherlands has the agency Senter Novem, which was put into operation in 2004. The Norwegian national authority, Innovation Norge, was established in 2004. Ireland implements its innovation strategy through Forfás, founded in 1994 (Atkinson \& Ezel, 2012).

Innovation policy should be oriented towards general and social challenges. Center of attention should be sophisticated innovation, and not only production of high technology products. The new model of cooperation management in the field of international science, technology and innovation 
Despotović $D$. et al.: Analysis of innovativeness, as a determinant of competitiveness...

presupposes the adoption of institutional arrangements, and the affirmation of financing model in the function of overcoming the global challenges and enable the widest diffusion of innovations. In particular, must work to accelerate the mobilization of international innovations and changes in the areas of national and regional innovation policy instruments. (Ministerial report on the OECD Innovation Strategy, 2010). The results of the thus-far conducted analysis indicate the causes and the situation at a given point in time. As the process of implementation of innovation is dynamic by nature, it is necessary to observe the selected groups of countries, from the standpoint of innovativeness, by introducing the time dimension.

\subsection{Time diagrams of innovativeness - 12th pillar of the GCI}

With regard to the formed clusters and a big established difference between them, the further course of the research includes the time dimension, and analyses the trend of innovativeness in the observed groups of countries (data available for a time period of ten years). Time series graphs for each of the clusters are designed, based on the indicators of Innovation (12 $2^{\text {th }}$ pillar) with average values per cluster, showing also the trend lines for each of the clusters (Fig. 8).

Figure 8. Time diagram of the 12th pillar of the GCl for the selected countries in the period 2006-2015

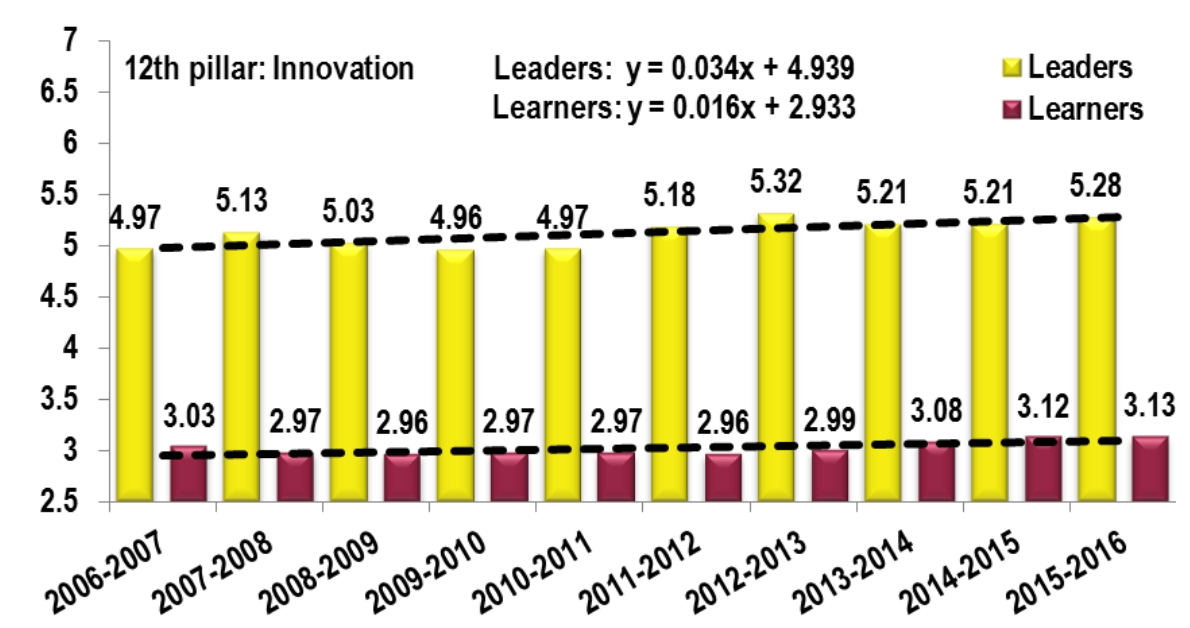

Source: Authors, with reference to: The Global Competitiveness Report 2006-2007; 2007-2008; 2008-2009; 2009-2010; 2010-2011; 2011-2012; 2012-2013; 2013-2014, 2014-2015, 2015-2016, World Economic Forum 
Despotović $D$. et al.: Analysis of innovativeness, as a determinant of competitiveness...

The estimated models of the trend, defined for the first and the second cluster and represented in Fig. 8, indicate that innovativeness within the cluster innovation leaders is at a much higher level in relation to the cluster innovation learners, as has been shown by the cluster analysis. This also confirms the hypothesis $\mathrm{H} 1$. However, as can be seen, the trend of innovativeness within the cluster per years is not pronounced, so that graphical representation corresponds to almost a straight line, at different levels. It can be visually concluded that if similar trends continue in the future, it is not realistic to expect that ceteris paribus the convergence of these lines will occur, i.e. it is not realistic to expect that the gap among the selected groups of countries, in terms of the level of innovativeness, will be reduced.

To check the existence of significant correlation between the observed series, it is first necessary to test their stationarity. By applying the unit root test, it is examined whether the time series are stationary or they have unit roots. For these purposes, Dickey-Fuller test is used, and the results are given in Tables 1 and 2.

Table 1 Dickey-Fuller test for the series LEAD

Null Hypothesis: LEAD has a unit root

Exogenous: Constant

Lag Length: 0 (Automatic - based on SIC, maxlag=1)

\begin{tabular}{llll} 
& & $\mathrm{t}$-Statistic & Prob. $^{*}$ \\
\hline Augmented Dickey-Fuller test statistic & -1.337992 & 0.5624 \\
\hline Test critical values: & 1\% level & -4.420595 & \\
& $5 \%$ level & -3.259808 & \\
& $10 \%$ level & -2.771129 &
\end{tabular}

Table 2 Dickey-Fuller test for the series LEARN

Null Hypothesis: LEARN has a unit root

Exogenous: Constant

Lag Length: 0 (Automatic - based on SIC, maxlag=1)

\begin{tabular}{llll} 
& & t-Statistic & Prob. $^{*}$ \\
\hline Augmented Dickey-Fuller test statistic & -0.863563 & 0.7426 \\
\hline Test critical values: & 1\% level & -4.582648 & \\
& $5 \%$ level & -3.320969 & \\
& $10 \%$ level & -2.801384 &
\end{tabular}

Based on the results of Dickey-Fuller test, as expected, it is found that both series have a unit root, i.e. that they are non-stationary. 
Despotović $D$. et al.: Analysis of innovativeness, as a determinant of competitiveness...

In this case, simple regression analysis is not suitable, which implies the need for a more complex analysis, requiring the formulation of VAR model (to allow for the analysis of dynamic relationships between variables).

VAR model is a framework for empirical analysis of mutual relations between the two observed time series: cluster of innovation leaders (LEAD) and cluster of innovation learners (LEARN). Time series are observed in the period 20062015. The analysis is conducted using the Eviews 7 software package.

In order to test the existence of significant correlation between the observed series (LEAD and LEARN), an empirical analysis resolves the dilemma of whether these series are cointegrated time series, whether there is a unidirectional causality between these series, and whether it is mutual. The results in Tables 3 and 4 indicate that these are cointegrated time series, and, therefore, there is a long-term correlation between LEAD and LEARN. As these two series are cointegrated, the corresponding VAR model is tested below.

Table 3 Cointegration test

Sample (adjusted): 20082015

Included observations: 8 after adjustments

Trend assumption: Linear deterministic trend

Series: LEAD LEARN

Lags interval (in first differences): 1 to 1

Unrestricted Cointegration Rank Test (Trace)

\begin{tabular}{|c|c|c|c|c|}
\hline Hypothesized & & Trace & 0.05 & \\
\hline No. of $\mathrm{CE}(\mathrm{s})$ & Eigenvalue & Statistic & Critical Value & Prob. ${ }^{* *}$ \\
\hline None * & 0.909598 & 25.55515 & 15.49471 & 0.0011 \\
\hline At most 1 * & 0.546565 & 6.327232 & 3.841466 & 0.0119 \\
\hline
\end{tabular}

Trace test indicates 2 cointegrating eqn(s) at the 0.05 level

* denotes rejection of the hypothesis at the 0.05 level

**MacKinnon-Haug-Michelis (1999) p-values

Table 4 Cointegration test

\begin{tabular}{lcccc}
\hline \multicolumn{6}{l}{ Unrestricted Cointegration Rank Test (Maximum Eigenvalue) } \\
\hline Hypothesized & & Trace & 0.05 & \\
\hline No. of CE(s) & Eigenvalue & Statistic & Critical Value & Prob. ** \\
\hline None ${ }^{*}$ & 0.909598 & 19.22792 & 14.26460 & 0.0076 \\
At most $1^{*}$ & 0.546565 & 6.327232 & 3.841466 & 0.0119 \\
\hline
\end{tabular}

Max-eigenvalue test indicates 2 cointegrating eqn(s) at the 0.05 level

* denotes rejection of the hypothesis at the 0.05 level

**MacKinnon-Haug-Michelis (1999) p-values 
Despotović $D$. et al.: Analysis of innovativeness, as a determinant of competitiveness...

In the process of selection of an appropriate model, VAR model of the second order is a priori selected. Data related to this model is given in Table 5.

Table 5 Results of the testing of VAR(2) model (LEAD and LEARN)

Vector Autoregression Estimates

Sample (adjusted): 20082015

Included observations: 8 after adjustments

Standard errors in () \& t-statistics in [ ]

\begin{tabular}{lcr}
\hline & LEARN & LEAD \\
\hline LEARN(-1) & 1.023191 & 4.221527 \\
& $(0.18369)$ & $(1.40223)$ \\
& {$[5.57010]$} & {$[3.01058]$} \\
\hline LEARN(-2) & -0.480425 & -3.174213 \\
& $(0.17990)$ & $(1.37324)$ \\
& {$[-2.67058]$} & {$[-2.31148]$} \\
\hline LEAD(-1) & 0.219599 & 0.890747 \\
& $(0.03786)$ & $(0.28898)$ \\
& {$[5.80079]$} & {$[3.08237]$} \\
\hline LEAD(-2) & 0.044881 & -1.494448 \\
& $(0.06632)$ & $(0.50622)$ \\
& {$[0.67679]$} & {$[-2.95217]$} \\
\hline C & 0.032996 & 5.014615 \\
& $(0.33647)$ & $(2.56849)$ \\
& {$[0.09806]$} & {$[1.95236]$} \\
\hline R-squared & 0.991495 & 0.859417 \\
Adj. R-squared & 0.980156 & 0.671974 \\
\hline
\end{tabular}

Bearing in mind the results of Table 6, it is found that the use of VAR (2) model is justified, and that 2 is the optimal number of lags. Specifically, all the proposed criteria suggest the same thing -2 as the optimal number of lags.

Based on the tested VAR (2) model, it is further examined whether there is simultaneous interdependence between LEAD and LEARN, i.e. whether LEAD causes LEARN, on the one hand, and whether LEARN causes LEAD, on the other hand. Application of Granger causality tests with the selected VAR model clearly shows that, between LEAD and LEARN, there is Granger causality in both directions (Table 7). This confirms the statistical significance of Hypothesis 2. 
Despotović $D$. et al.: Analysis of innovativeness, as a determinant of competitiveness...

Table 6 Tests for the selection of the optimal number of lags

VAR Lag Order Selection Criteria

Endogenous variables: LEARN LEAD

Exogenous variables: $\mathrm{C}$

Sample: 20062015

Included observations: 8

\begin{tabular}{cllllll}
\hline Lag & LogL & LR & FPE & AIC & SC & HQ \\
\hline 0 & 16.59683 & NA & $8.94 \mathrm{e}-05$ & -3.649208 & -3.629348 & -3.783159 \\
1 & 28.37994 & 14.72889 & $1.38 \mathrm{e}-05$ & -5.594986 & -5.535404 & -5.996837 \\
2 & 41.96311 & $10.18737^{*}$ & $1.79 \mathrm{e}-06^{*}$ & $-7.990777^{*}$ & $-7.891475^{*}$ & $-8.660529^{*}$ \\
\hline
\end{tabular}

* indicates lag order selected by the criterion

LR: sequential modified LR test statistic (each test at $5 \%$ level)

FPE: Final prediction error

AIC: Akaike information criterion

SC: Schwarz information criterion

$H Q$ : Hannan-Quinn information criterion

Table 7 Results of the Granger causality test (LEAD and LEARN)

VAR Granger Causality/Block Exogeneity Wald Tests

Sample: 20062015

Included observations: 8

\section{Dependent variable: LEARN}

\begin{tabular}{llll}
\hline Excluded & Chi-sq & df & Prob. \\
\hline LEAD & 43.51228 & 2 & 0.0000 \\
\hline All & 43.51228 & 2 & 0.0000
\end{tabular}

\section{Dependent variable: LEAD}

\begin{tabular}{llll}
\hline Excluded & Chi-sq & df & Prob. \\
\hline LEARN & 9.227272 & 2 & 0.0099 \\
\hline All & 9.227272 & 2 & 0.0099
\end{tabular}

The existence of causality between LEAD and LEARN is clearly seen with impulse response functions (Figure 9). LEARN response to LEAD onestandard-deviation shock throughout the three-year period will be positive, with an upward trend, during the observed period. LEAD response to LEARN standard-deviation in the first year will be negative, and in other years it will be positive with the upward trend. 
Despotović $D$. et al.: Analysis of innovativeness, as a determinant of competitiveness...

Figure 9 Impulse response function
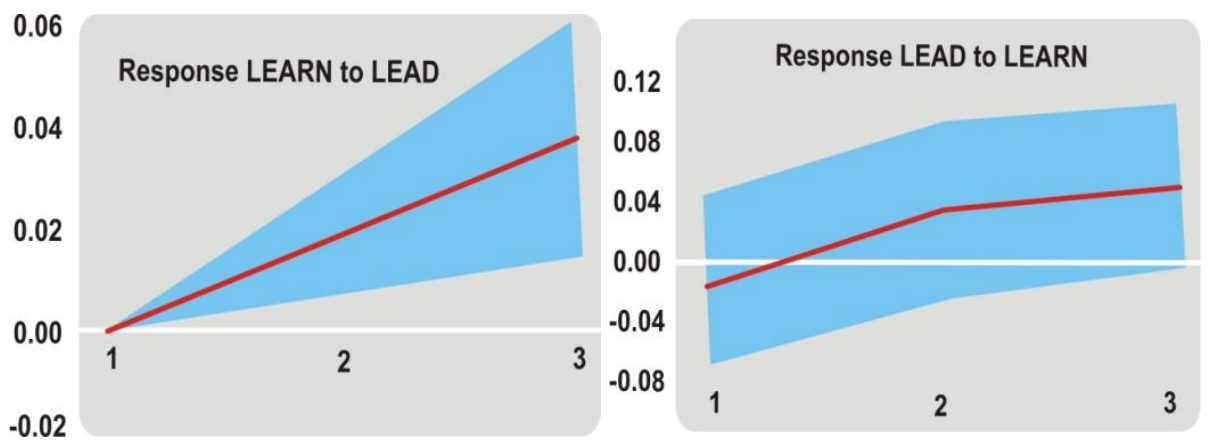

Between the observed series (LEARN and LEAD), statistically significant interdependence is established. The above-mentioned interdependence is unbalanced in the sense that EU learners' response to changes in EU leaders' innovativeness is positive with clearly pronounced upward trend, while the impact of changes in their innovativeness on EU leaders is of variable character (in the initial period of prediction, it is negative prediction, and later positive, with the upward trend of variable slope). With a high level of abstraction, this can be seen as a potential benefit that EU learners can get from their neighbouring EU leaders. This potential can be transformed into real innovation capacity of EU learners, through activities that must be accompanied by strategic management, as well as continuous fine adjustment, and the harmonisation of national, regional, and even EU innovation policies.

\subsection{The interdependence of innovativeness and GDP per capita}

Fig. 10 presents the scatter diagrams and linear form of interdependence between innovativeness and GDP per capita for the examined group of countries, which contain additional information about the competitiveness, expressed by the size of the balloon (where the used pairs of data relate to the period of eight years). 
Despotović $D$. et al.: Analysis of innovativeness, as a determinant of competitiveness...

Figure 10. Scatter diagram and linear form of interdependence of 12th pillar of the GCl(innovation) and GDP per capita for the examined groups of countries for the period 2006-2013
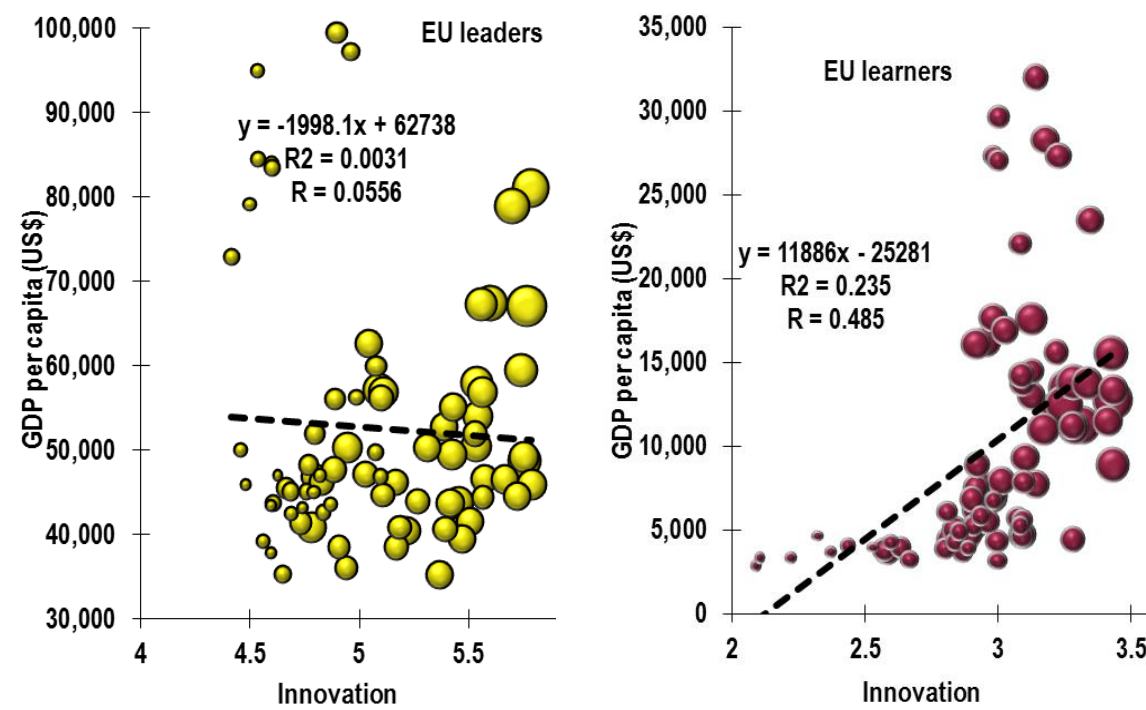

Source: Authors, with reference to: The Global Competitiveness Report 2006-2007; 2007-2008; 2008-2009; 2009-2010; 2010-2011; 2011-2012; 2012-2013; 2013-2014, World Economic Forum

For a group of innovative leaders, the interdependence of variables $12^{\text {th }}$ pillar Innovation and GDP per capita, PPP expressed through simple linear correlation coefficient, $r=-0.0556$, is insignificant correlation in terms of intensity. From the aspect of direction, it is the inverse correlation.

For a group of innovative learners, the interdependence of variables $12^{\text {th }}$ pillar Innovation and GDP per capita, expressed in purchasing power of the domestic currency and shown through simple linear correlation coefficient, $r=$ 0.485 , is significant correlation in terms of intensity. From the aspect of direction, it is a direct correlation.

Without going deeper into testing the statistical significance of the linear form of interdependence, in the analysis below, due to the extremely small value of the coefficient of determination for the first group of countries, the testing of the hypothesis on the significance of linear interdependence was confirmed only for the second group of countries (Table 8). 
Despotović $D$. et al.: Analysis of innovativeness, as a determinant of competitiveness...

Table 8. Summary of single regression analysis ((1) EU leaders, (2) EU learners countries)

Dependent variable:

\begin{tabular}{|c|c|c|}
\hline & \multirow[b]{2}{*}{ (y1) - EU leaders } & \multirow[b]{2}{*}{ (y2) - EU learners } \\
\hline & & \\
\hline$x 1$ & $-1,998.104$ & $11,886.450^{\pi \times x}$ \\
\hline & $(4,089.092)$ & $(2,444.038)$ \\
\hline \multirow[t]{2}{*}{ Constant } & $62,737.850^{x \times x}$ & $-25,280.550^{\mathrm{xx}}$ \\
\hline & $(20,898.000)$ & $(7,296.217)$ \\
\hline Observations & 80 & 79 \\
\hline $\mathrm{R}^{2}$ & 0.003 & 0.235 \\
\hline Adjusted $\mathrm{R}^{2}$ & -0.010 & 0.225 \\
\hline Residual Std. Error & $14,753.570(\mathrm{df}=78)$ & $6,339 \cdot 635(\mathrm{df}=77)$ \\
\hline F Statistic & $0.239(\mathrm{df}=1 ; 78)$ & $23.653^{x * x}(\mathrm{df}=1 ; 77)$ \\
\hline Note: & & $p<0.1 ; p<0.05 ; ;^{\kappa \times} p<0.0$ \\
\hline
\end{tabular}

Source: Authors, with reference to: The Global Competitiveness Report 2006-2007; 2007-2008; 2008-2009; 2009-2010; 2010-2011; 2011-2012; 2012-2013; 2013-2014, World Economic Forum

Testing the hypothesis on linear interdependence of the studied variables gives the value of the test statistics of 23.653. With a probability of the level of test significance of 0.01 it is concluded that there is a linear interdependence between the observed variables that is statistically significant. Therefore, abstracting the importance of other factors, it can be concluded that for a group of innovation learners, innovativeness is an important factor of economic growth. This means that through intensification of investment in research and development, especially by the private sector, raising the quality of scientific research institutions, particularly those that support the creation and mass diffusion of new technologies, as well as wider collaboration between universities and industry in the field of research and development, innovation learners can expect acceleration of innovativeness, which will, ceteris paribus, have a positive impact on the level of pc GDP, expressed by PPP. This supports the hypothesis H3.

\section{Conclusion}

The results of cluster analysis, based on the parameters of innovativeness, confirm the existence of a deep gap between European innovation leaders and innovation learners in 2013. The most striking divergence of the observed groups of countries relates to the elements of innovativeness University- 
Despotović $D$. et al.: Analysis of innovativeness, as a determinant of competitiveness...

industry collaboration in R\&D and Quality of scientific research institutions, and the least in respect of Availability of scientists and engineers and PCT patents applications/million population. Assuming that similar tendencies in innovativeness of the economy of the observed clusters of countries continue, the conclusion is that their convergence in terms of innovativeness should not be expected.

The detected intensity and character of interdependence of time series, EU leaders' innovativeness and EU learners' innovativeness, indicate a positive potential which less developed EU economies could use. In this way, EU learners would bring their innovation capacity closer to innovatively advanced EU neighbours. Of course, as already mentioned, this must be accompanied by strategic management, as well as continuous fine adjustment, and the harmonisation of national, regional, and even EU innovation policies.

For a group of innovative leaders, the interdependence of variables Innovation and GDP per capita, expressed in purchasing power of the domestic currency and shown through simple linear correlation coefficient is insignificant correlation in terms of intensity. From the aspect of direction, it is the inverse correlation. In contrast, in respect of a group of innovative learners, in terms of intensity, there is a significant correlation. From the aspect of direction, it is a direct correlation. Therefore, abstracting the importance of other factors, the conclusion is that for a group of innovation learners, improving innovativeness stands for an important assumption of growth of GDP pc in the future period. This also points to the strategic importance of improving innovativeness and implementation of an efficient innovation policy, as an increasingly important component of the economic policies of these countries.

\section{References}

Amidon, D. (2003) The Innovation Highway, Butterworth-Heinemann, Boston.

Atkinson, R., \& Ezell, S. (2012) Innovation Economics - The Race For Global Advantage, Yale University Press, London.

Boia, M., Conceição, P., \& Santos, R. (2003) Determinants of Innovation in Portugal: Designing, Implementing and Analyzing Evidence from the Third Community Innovation Survey, Instituto Superior Técnico, Lisbon.

Bolwijn, P., \& Kump, T. (1990) Manufacturing in the 1990s: Productivity, Flexibility and Innovation, Long Range Planning 23 (4): 44-57.

Cimoli, M., \& Dosi, G. (1995) Technological Paradigms, Patterns of Learning and Development: An Introductory Roadmap, Journal of Evolutionary Economics 5(3): 243-268.

Cvetanovic, S., Despotović, D., Mladenović, I., \& Jovović, D. (2014). The analysis of innovation in Western Balkan countries in 2012. Economic ResearchEkonomska Istraživanja, 27(1), 830-846. 
Despotović $D$. et al.: Analysis of innovativeness, as a determinant of competitiveness...

Despotovic, D. Z., Cvetanović, S. Ž., \& Nedić, V. M. (2014). Innovativeness and competitiveness of the Western Balkan countries and selected EU member states. Industrija, 42(1), 27-45.

Dodgston, M.,Gann, D., \& Salter, A. (2008) The Management of Technological Innovation: Strategy and Practice, Oxford University Press, Oxford.

Dutta, S. (ed.) (2012) Global Innovation Index 2011/12, INSEAD and WIPO, Fontainebleau.

Edquist, C. (ed.) (1997) Systems of Innovation: Technologies, Institutions and Organizations, Pinter Publishers, London.

EU Innovation, (2005) The Evaluation Process in Innovation Policy, Study Working Paper, accessed at: http://www.euinnovation.net/innovation_evaluation/htm/ pilot.htm on 05September 2014.

European Commission (2009) Final report of the Bussines Panel on future innovation policy, Reinvent Europe Through Innovation, From a Knowledge Society to Innovation Society, accessed at http://ec.europa.eu/enterprise/policies/innovation/files/panel_report_en.pdf on 03 October 2014.

Fagerberg, J., Mowery, D., \& Nelson, R. (2004) Innovation, Oxford University Press, Oxford.

Foray, D., \& Phelps, E. (2010) The Challenge of Innovation in Turbulent Times: A Report Submitted to the Global Agenda Council, Working Paper No. 56, April, Columbia University, Center on Capitalism and Society, New York.

Freeman, C. (1987) Technology Policy and Economic Performance: Lessons from Japan, Francis Pinter, London.

Freeman, C. (1995) The 'National System of Innovation' in Historical Perspective. Cambridge Journal of Economics, 19(1):5-24.

Freeman, C. (2002) Continental, National and Sub-National Innovation Systems Complementarity and Economic Growth. Research Policy, 31(2): 191-211.

Freeman, C. (2008) Systems of Innovation: Selected Essays in Evolutionary Economics, Edward Elgar, Cheltenham UK/Nothampton, MA.

Greenhalgh, Ch., \&Rogers, M. (2010) Innovation, intellectual property, and economic growth, Princeton University Press, New Jersey.

Hujer, R., \& Radic, D. (2005), Evaluating the Impacts of Subsidies on Innovation Activities in Germany, Scottish Journal of Political Economy, 52(4):565-586.

Jobber, D. (2001) Principles and Practice of Marketing. 4th ed. McGraw-Hill International Ltd, Berkshire.

Lundvall, B. (ed.) (1992) National systems of innovation: Towards a theory of innovation, Palgrave, London.

Nedic, V. M., Cvetanović, S. Ž., \& Despotovic, D. Z. (2014). ICT as a component of knowledge economy development of Western Balkan countries. Industrija, 42(4), 55-77.

OECD (2010) Economics: Innovation Central to Boosting Growth and Jobs, accessed at

http://www.oecd.org/sti/inno/ economicsinnovationcentraltoboostinggrowthandjobs.htm on 27 May 2014

Porter, M., \& Rivkin, J. (2012) The looming challenge to U.S. competitiveness, Harvard Business Review, 90(3):54-61.

Rothwell, R. (1994) Towards the Fifth-Generation Innovation Process. International Marketing Review, 11(1): 7-31.

Smith, D. (2010) Innovation, McGraw Hill, London. 
Despotović $D$. et al.: Analysis of innovativeness, as a determinant of competitiveness...

Takalo, T., Tanayama, T., \& Toivanen, O. (2008) Evaluating innovation policy: a structural treatment effect model of R\&D subsidies, Bank of Finland Research Discussion Papers, 7/2008, Finland.

World Economic Forum The Global Competitiveness Report 2006-2007; 2007-2008; 2008-2009; 2009-2010; 2010-2011; 2011-2012; 2012-2013; 2013-2014, 20142015; 2015-2016, Geneva.

World Economic Forum (2012) The Europe 2020 Competitiveness Report: Building a More Competitive Europe, Global Competitiveness Network, Geneva.

Zahra S Jennings D and Kuratko D (1999) The Antecedents and Consequences of Firm-level Entrepreneurship: the State of the Field, Entrepreneurship Theory and Practice 24(2):45-65.

Zubović, J. (2012). Human capital development as a tool for managing structural changes-secondary education vs. structural changes. Managing Structural Changes: Trends and Requirements, 412-426. 